
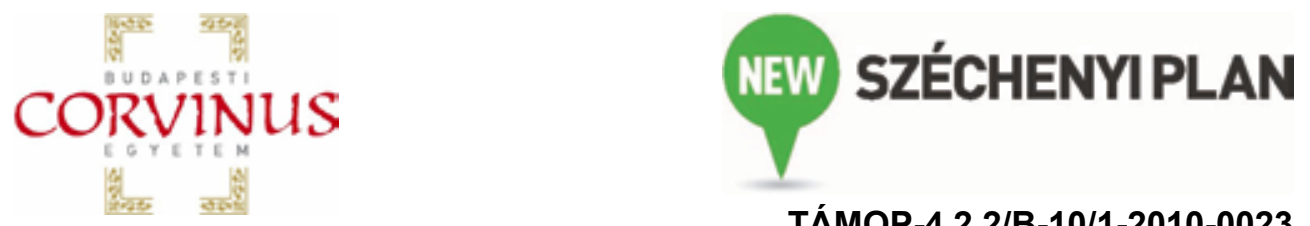

TÁMOP-4.2.2/B-10/1-2010-0023

\title{
PREFACE TO THE SPECIAL ISSUE ON FOOD RESEARCH ACTIVITIES OF UNDERGRADUATE STUDENTS AT DIFFERENT TALENT-CELLS OF FACULTY OF FOOD SCIENCE, CORVINUS UNIVERSITY OF BUDAPEST
}

In Hungary a number of open-minded students groups have been traditionally formed and are present in the educational/schooling system from primary schools to universities already for decades. In the higher education deeply rooted self-training activities were brought to life from the early ninety-fifties revealing the intention of students to pursue also this form of self-learning, their demand on quality education as well as the manifestation of a young generation of scientists. Today at the universities, one of the most important forms of talent support is the so called Students' Scientific Circle (Tudományos Diákkör, TDK), which is one of the main pillars of the National Talent Programme started in 2008.

Historically, the TDK activities of undergraduate students at the Faculty of Food Science dates back more than 40 years. In recent years, the interest of undergraduate students has increased significantly in this form of self-training, thus today it has a significant role in the training the future R\&D specialists. These activities fit perfectly into the development strategy of human resources at the Faculty. Through TDK activities, talented students have the opportunity to evaluate the literature background of the topics of interest and to learn new and modern physical, chemical, biological, and molecular biological methods over their regular studies. Moreover, they can also join different projects focusing on development and application of new technologies in food science and management of wastes that should result in a reduced-waste, environment-friendly production process. Other outcomes of the TDK activities are also the opportunity to take part in workshops, research group meetings (with posters and oral presentations), where they can expand their scientific knowledge, meet scientists from other institutions from home and abroad, as well as they also learn the rules of ethics of scientific research and teamwork.

This special issue consists of 13 quality papers selected from the contribution talks and theses of various TDK Conferences in the last two years. The results presented here, such as the application of electronic nose or tongue in the assessment of quality of foods, technological development and evaluation of bioactive food additives (antioxidants, pre- and probiotics), foods with special functions, or of utilisation of by-products as well as of different fermentation processes or efficient preservation methods, contribute to our present knowledge of the given field. These works were carried out by the TDK students under the supervision of the lecturerscientists at different talent-cells of the Faculty of Food Science of the Corvinus University 
of Budapest. Hopefully through this issue readers will not only get insights into the TDK works of our Faculty, but also receive significant scientific results from different fields of food research.

This special issue has been financed by the National Development Agency through project No. TÁMOP-4.2.2/B-10/1-2010-0023 entitled: Comprehensive development of scientific training centers at Corvinus University of Budapest and National University of Public Service.

Judit M. REZESSY-SZABÓ president of Committee of TDK

Faculty of Food Science, Corvinus University of Budapest

Quang D. NGuyen secretary of Committee of TDK

Faculty of Food Science, Corvinus University of Budapest 